\title{
Sifat Fisik dan Penerimaan Roti Tawar dari Tepung Komposit Terigu dan Singkong dengan Variasi Lama Pencampuran Adonan
}

\author{
Physical Characteristics and Sensory Acceptance of Bread from Composite Wheat and Cassava Flours with \\ Variation in Dough Mixing Time
}

Rusdin Rauf*, Khasanah Tri Andini

\author{
Program Studi Ilmu Gizi, Fakultas Ilmu Kesehatan, Universitas Muhammadiyah Surakarta, \\ Jl. Ahmad Yani, Kartasura, Surakarta, Jawa Tengah 57169, Indonesia \\ *Email: rusdin.rauf@ums.ac.id
}

Tanggal submisi: 02 Desember 2018; Tanggal penerimaan: 14 Mei 2019

\begin{abstract}
ABSTRAK
Penelitian ini bertujuan untuk mengevaluasi sifat fisik dan penerimaan sensorik roti tawar dari variasi rasio tepung komposit terigu dan singkong dan variasi lama pencampuran adonan. Penelitian dilakukan dengan 4 variasi rasio tepung terigu dan singkong yaitu 100:0, 90:10, 80:20 dan 70:30, sedangkan variasi lama pencampuran yaitu 10, 15 dan 20 menit pada pembuatan adonan. Parameter yang dianalisis pada adonan roti tawar meliputi tingkat pengembangan dan elongasi, sedangkan pada roti tawar yaitu tingkat pengembangan, kekerasan, elastisitas dan penerimaan. Hasil penelitian menunjukkan bahwa makin tinggi proporsi tepung singkong, semakin rendah tingkat pengembangan adonan. Meskipun lama pencampuran berpengaruh terhadap tingkat pengembangan adonan, namun tidak memberikan kecenderungan yang meningkat atau menurun dengan semakin meningkatnya proporsi tepung singkong. Tingkat pengembangan adonan tertinggi adalah perlakuan tepung komposit 90:10 (15 menit). Tensile strength dan strain adonan roti menunjukkan kecenderungan menurun dengan semakin meningkatnya proporsi tepung singkong, sedangkan lama pencampuran adonan, meskipun memberikan pengaruh terhadap tensile strength dan strain, namun tidak memberikan kecenderungan yang konsisten. Kedua indikator tersebut menunjukkan titik tertinggi yang sama yaitu pada perlakuan 100:0 (15 menit). Tingkat pengembangan roti tawar menunjukkan penurunan dengan semakin meningkatnya proporsi tepung singkong. Pengembangan roti tawar tertinggi diberikan oleh tepung komposit 90:10, namun tidak ada pengaruh lama pencampuran pada perlakuan ini. Makin tinggi proporsi tepung singkong, semakin tinggi kekerasan roti tawar, sedangkan elastisitas roti tawar menunjukkan kecenderungan yang sebaliknya yaitu makin rendah dengan semakin meningkatnya proporsi tepung singkong. Kedua indikator tekstur roti tersebut dipengaruhi oleh lama pencampuran, namun tidak memberikan kecenderungan tertentu yang meningkat atau menurun dengan semakin meningkatnya proporsi tepung singkong. Kekerasan roti tawar tertinggi diberikan oleh perlakuan 70:30, sedangkan elastisitas tertinggi adalah perlakuan 100:0. Skor penerimaan roti tawar tertinggi adalah perlakuan 90:10 yang tidak berbeda nyata dengan 100:0.
\end{abstract}

Kata kunci: Penerimaan; roti; singkong; pencampuran; tekstur

\begin{abstract}
This study was aimed to find out the physical characteristics and sensory acceptance of bread made from different variations of wheat and cassava composite flour ratio, and the dough's mixing duration. The research was conducted experimentally with 4 ratio variations of wheat and cassava flours, namely 100:0, 90:10, 80:20 and 70:30, and 3 variations of dough mixing duration, namely 10 minutes, 15 minutes and 20 minutes. The analyzed parameters for dough were the development and the elongation, and for bread were the development, hardness, elasticity, and acceptance. The results showed that the higher the cassava flour proportion, the lower the level
\end{abstract}


of dough development. The dough development was affected by mixing duration, but there was no increasing tendency of the cassava flour. The treatment of 100:0 (15 minutes), which was not significantly different from 90:10 (15 minutes), indicated the highest dough development. The higher the cassava flour proportion, the lower the dough's tensile strength and the strain, while the mixing duration showed the influence on the dough's tensile strength and strain. Both indicators gave the same highest point, it was the treatment of 100:0 (15 minutes). The bigger the cassava flour proportion, the lower the bread development. The highest bread development was given by 100:0 treatment, but there was no effect of mixing time on this treatment. The bigger the cassava flour proportion, the higher the bread's hardness, while for the bread's elasticity, it showed the opposite, the higher cassava flour, the lower the bread's elasticity. The two bread texture indicators were influenced by the mixing time but did not provide a steady tendency toward the increasing proportion of cassava flour. The highest bread hardness was indicated by the 70:30 treatment, while the biggest bread elasticity was with the treatment of 100:0. The highest acceptance of bread was revealed by 100:0 treatment, which was not significantly different from 90:10 treatment.

Keywords: Acceptance; bread; cassava; mixing; texture

\section{PENDAHULUAN}

Tepung terigu sebagai salah satu bahan baku berbagai produk pangan olahan, konsumsinya di Indonesia cenderung mengalami peningkatan. Sejak tahun 2012 hingga tahun 2016, terjadi peningkatan konsumsi tepung terigu rata-rata $4,2 \%$. Pada tahun 2012 konsumsi tepung terigu sebesar $20,6 \mathrm{~kg} / \mathrm{kap} /$ tahun, mengalami peningkatan menjadi $22,3 \mathrm{~kg} / \mathrm{kap} /$ tahun pada tahun 2016 (APTINDO, 2018). Data ini seiring dengan peningkatan konsumsi roti tawar di Indonesia. Pada tahun 2014 konsumsi roti tawar sebesar 0,062 bungkus kecil/kap/tahun, kemudian mengalami peningkatan pada tahun 2017 menjadi 0,367 bungkus kecil/kap/tahun (Kementan, 2017).

Meningkatnya konsumsi tepung terigu perlu diantisipasi karena dapat memberikan dampak buruk bagi kesehatan, khususnya anak. Masalah kesehatan ini dihubungkan dengan adanya gluten pada tepung terigu dan produk olahannya. Konsumsi gluten dapat menyebabkan penyakit celiac pada anak yang merupakan gangguan auto-immun (Niland dan Cash, 2018). Anakanak yang mengalami nephrotyc syndrome sangat sensitif terhadap gluten (Lemley dkk., 2016). Kondisi ini perlu mendapatkan penanganan, salah satu upaya yang dapat dilakukan adalah mengurangi tepung terigu khususnya pada produk roti dengan mensubstitusikan tepung singkong.

Substitusi tepung singkong pada pembuatan roti tawar menyebabkan penurunan mutu roti tawar (Nwosu dkk., 2014; Eriksson dkk., 2014). Berbagai faktor yang memengaruhi penurunan mutu tersebut adalah selain komponen kimia penyusun dari campuran tepung, juga dipengaruhi oleh volume air yang digunakan (Shewry dkk., 2001) dan proses pengolahan, khususnya fermentasi (Casado dkk., 2017) dan pencampuran (Scanlon dan Zghal, 2001).
Upaya mengatasi masalah penurunan mutu tersebut telah dilaporkan oleh Rauf dan Sarbini (2015) melalui teknik proporsional untuk menghitung volume air yang digunakan pada preparasi adonan dari tepung komposit terigu dan singkong yang didasarkan pada daya serap air campuran tepung tersebut. Rauf dkk. (2017) juga telah melaporkan sifat fisik dan sensori roti tawar dari tepung komposit terigu dan singkong dengan volume air yang ditentukan secara proporsional terhadap daya serap air tepung. Lama pencampuran adonan dalam pembuatan roti dipengaruhi oleh jenis tepung (Gomez dkk., 2011). Milcah dkk., (2016) menyatakan bahwa tepung terigu dan tepung singkong memiliki karakteristik kimia dan fisik yang berbeda, yang berdampak pada lama pencampuran yang berbeda untuk membentuk adonan yang optimum dalam tingkat pengembangan dan sifat elongasi. Berdasarkan berbagai acuan tersebut, penelitian terntang pencampuran adonan dari tepung komposit terigu dan singkong pada pembuatan roti tawar perlu dilakukan. Tujuan penelitian ini adalah untuk mengevaluasi pengaruh lama pencampuran adonan terhadap tekstur dan daya terima roti tawar.

\section{METODE PENELITIAN}

\section{Bahan}

Bahan utama yang digunakan dalam penelitian ini adalah tepung terigu (hard flour), air, margarin, garam, gula, yeast, pengemulsi dan singkong. Singkong diperoleh dari petani di Boyolali, Jawa Tengah, Indonesia yang berumur 9 bulan. Alat
Peralatan yang digunakan dibagi atas peralatan
untuk pembuatan tepung, pembuatan roti dan 
pengujian. Alat utama pembuatan tepung singkong adalah grinder dan mesin pengayak. Pembuatan roti tawar menggunakan alat utama oven elektrik. Alat pengujian yaitu Universal Testing Machine, model Z0.5, Zwick Roell AG, Germany, untuk analisis elongasi adonan roti tawar, kekerasan roti tawar dan elastisitas roti tawar.

\section{Pembuatan Tepung Singkong}

Tepung singkong dibuat sesuai prosedur Masamba dan Jinazali (2014). Singkong dikupas kemudian dicuci menggunakan air yang mengalir. Singkong diiris tipis kemudian dikeringkan menggunakan sinar matahari selama 3 hari. Selanjutnya dilakukan penepungan menggunakan grinder dan pengayakan dengan ayakan 80 mesh.

\section{Pembuatan Adonan}

Pembuatan adonan roti tawar mengikuti prosedur Rauf dkk. (2017) dengan modifikasi pada lama pencampuran adonan. Komposisi bahan yang dgunakan berupa tepung komposit (200 g), margarin (4 g), gula $(4 \mathrm{~g})$, yeast $(4 \mathrm{~g})$, garam $(4 \mathrm{~g})$, pengemulsi $(4 \mathrm{~g})$ dan air. Semua bahan dicampur dengan lama waktu sesuai perlakuan yaitu 10, 15 dan 20 menit, kemudian difermentasi dengan waktu sesuai dengan titik optimum fermentasi dari setiap variasi rasio tepung komposit dan lama pencampuran yang diperoleh dari hasil penelitian ini. Lama fermentasi adonan diberikan pada Tabel 1.

\section{Tingkat Pengembangan Adonan}

Pengukuran tingkat pengembangan adonan mengikuti Codina dkk. (2013) dan Rauf dkk. (2017). Adonan dibuat sesuai dengan tahapan sebelumnya, selanjutnya dimasukkan ke dalam gelas beker dan kemudian difermentasi selama 100 menit. Setiap 5 menit selama fermentasi, dilakukan pengukuran tinggi adonan. Lama fermentasi yang optimum digunakan sebagai acuan untuk tahap penelitian selanjutnya.

\section{Elongasi Adonan}

Adonan yang telah difermentasi sesuai dengan titik optimum kemudian dilakukan pengujian elongasi. Analisis elongasi mengacu pada Uthayakumaran dkk. (2000) dan Rauf dkk. (2017). Adonan diletakkan di antara dua plat dari Universal Testing Machine. Bagian sisi plat yang berhadapan, ditempelkan kertas amplas nomor 100 yang dapat membuat adonan merekat kuat saat ditarik. Adonan kemudian di tarik dengan kekuatan $50 \mathrm{~mm} /$ menit. Tensile strength menggambarkan kekuatan adonan dalam menahan deformasi dan nilai strain menggambarkan tingkat kemuluran adonan.

\section{Pembuatan Roti Tawar}

Pembuatan roti tawar sesuai prosedur Rauf dkk. (2017), yaitu diawali dengan pembuatan adonan seperti pada prosedur sebelumnya. Setelah proses fermentasi, adonan dipanggang pada suhu $150^{\circ} \mathrm{C}$ selama 20 menit

\section{Pengukuran Tekstur}

Pengukuran kekerasan dan elastisitas roti tawar mengunakan Universal Testing Machine model Z0.5, Zwick/Roell AG, Germany. Pengukuran kekerasan mengikuti prosedur Artan dkk. (2010) dan Rauf dkk. (2017). Roti tawar diletakkan di atas plat Universal Testing Machine kemudian diberi tekanan kompresi hingga mengalami deformasi. Besarnya maksimum gaya untuk mendeformasi roti tawar menunjukkan tingkat kekerasan roti. Elastisitas adalah perbandingan antara tinggi roti setelah diberikan tekanan kemudian direlaksasi dengan tinggi roti sebelum diberikan tekanan.

\section{Uji Penerimaan}

Pengujian daya terima telah mendapatkan surat kelaikan etik (Ethical Clearance Letter) dengan nomor 1155/B.1/KEPK-FKUMS/IV/2018. Uji daya terima dilakukan oleh 30 orang panelis tidak terlatih dari program studi Ilmu Gizi, Universitas Muhammadiyah Surakarta, dengan metode yang mengacu pada Lawless dan Heymann (2010), dan Breshears dan Crowe (2013) dengan perbedaan pada jumlah skala hedonik. Atribut yang diuji meliputi kesukaan terhadap warna, aroma, cecap, tekstur dan keseluruhan. Pengujian daya terima menggunakan 7 skala hedonik yaitu $1=$ sangat tidak suka, $2=$ tidak suka, $3=$ agak tidak suka, $4=$ netral, $5=$ agak suka, $6=$ suka dan $7=$ sangat suka.

\section{Rancangan Penelitian dan Analisis Data}

Rancangan penelitian menggunakan acak kelompok (RAK), yang terdiri atas 2 faktor. Faktor pertama yaitu

Tabel 1. Lama fermentasi adonan dari perlakuan tepung komposit dan lama pencampuran

\begin{tabular}{lcccccccccccc}
\hline Rasio tepung & \multicolumn{3}{c}{$100: 0$} & \multicolumn{3}{c}{$90: 10$} & \multicolumn{3}{c}{$80: 20$} & \multicolumn{3}{c}{$70: 30$} \\
\hline Pencampuran (menit) & 10 & 15 & 20 & 10 & 15 & 20 & 10 & 15 & 20 & 10 & 15 & 20 \\
Fermentasi (menit) & 60 & 50 & 55 & 65 & 60 & 55 & 50 & 55 & 50 & 45 & 55 & 40 \\
\hline
\end{tabular}


variasi tepung komposit terigu dan singkong 100:0, 90:10, 80:20 dan 70:30. Faktor kedua yaitu variasi lama pencampuran adonan yaitu 10, 15 dan 20 menit.

Data dianalisis menggunakan One-way Anova untuk data yang terdistribusi normal, sedangkan data yang tidak terdistribusi normal menggunakan KruskalWallis. Perbedaan hasil dianalisis menggunakan Duncan's Multiple Range Test (DMRT) pada taraf signifikansi 0,05.

\section{HASIL DAN PEMBAHASAN}

\section{Tingkat Pengembangan Adonan}

Hasil penelitian menunjukkan adanya pengaruh tepung komposit terigu dan singkong dan lama pencampuran terhadap tingkat pengembangan adonan roti tawar. Gambar 1, menunjukkan tingkat pengembangan adonan yang semakin rendah dengan semakin besarnya rasio tepung singkong. Tingkat pengembangan adonan roti tawar tertinggi ditunjukkan oleh adonan 90:10 (15 menit) yang berbeda tidak nyata dengan 100:0 (15 menit), sedangkan tingkat pengembangan adonan terendah ditunjukkan oleh adonan roti tawar 70:30 (10 menit). Hasil ini sesuai dengan laporan Rauf dkk. (2017), bahwa makin besar rasio singkong, semakin kecil pengembangan adonannya. Rozylo dkk. (2015) menjelaskan bahwa perbedaan bahan baku yang digunakan berpengaruh terhadap tingkat pengembangan adonan. Rauf dkk. (2017) menyatakan bahwa makin besar rasio tepung terigu, semakin besar tingkat pengembangan adonan. Hal ini terkait dengan kandungan gluten pada tepung terigu. Menurut Dhaka dan Khatkar (2015), komponen utama pembentuk polimer gluten adalah gliadin dan glutenin.

Secara umum, waktu optimum pencampuran adonan yang menghasilkan tingkat pengembangan tertinggi adalah 15 menit. Pencampuran yang dilakukan
10 menit tergolong kurang, sedangkan pencampuran yang dilakukan selama 20 menit tergolong berlebih (overmixing). Sroan dkk. (2009), melaporkan bahwa saat pencampuran adonan dapat terjadi interaksi antara gluten dan pati. Jaringan gluten dapat mengembang ketika terjadi depolimerisasi komponen gliadin yang berinteraksi dengan glutenin. Hal tersebut dapat menyebabkan terbentuknya matriks yang dapat menahan gas selama proses fermentasi. Gomez dkk. (2001), melaporkan bahwa selain dapat merusak struktur gluten, overmixing juga dapat menyebabkan terjadinya pemecahan matriks protein. Pecahnya matriks protein dapat membuat adonan roti menjadi tidak kuat sehingga adonan yang dihasilkan tidak dapat mengembang secara maksimal. Mirsaeedghazi dkk. (2008), melaporkan bahwa adonan yang tidak dapat mengembang secara maksimal dapat terjadi karena terjadinya deformasi dari ikatan-ikatan silang non-kovalen dan ikatan-ikatan disulfida selama proses pencampuran.

\section{Elongasi Adonan}

Secara statistik menunjukkan adanya pengaruh nyata dari variasi rasio tepung komposit terigu dan singkong terhadap tensile strength adonan. Data pada Gambar 2 menunjukkan bahwa makin besar rasio tepung singkong, tensile strength adonan semakin kecil. Nilai tensile strength tertinggi ditunjukkan oleh adonan roti tawar 100:0 (15 menit) yang tidak berbeda nyata dengan 90:10 (15 menit), sedangkan tensile strength terendah ditunjukkan oleh adonan 70:30 (10 menit). Rauf dan Sarbini (2015) menyatakan bahwa makin besar level penggunaan tepung singkong dalam pembuatan roti maka makin kecil nilai tensile strength. Menurut Mirsaeedghazi dkk. (2008), tingginya nilai tensile strength dihubungkan dengan adanya gluten pada tepung terigu. Weiser (2007), melaporkan bahwa

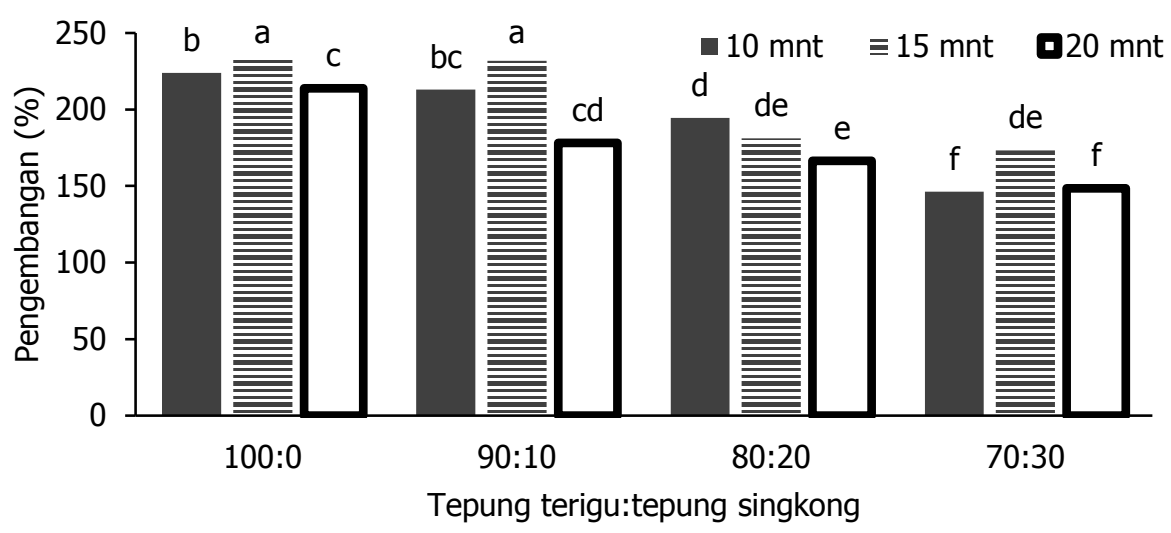

Gambar 1. Pengembangan adonan roti dari komposit tepung terigu dan tepung singkong dengan variasi lama pencampuran adonan 


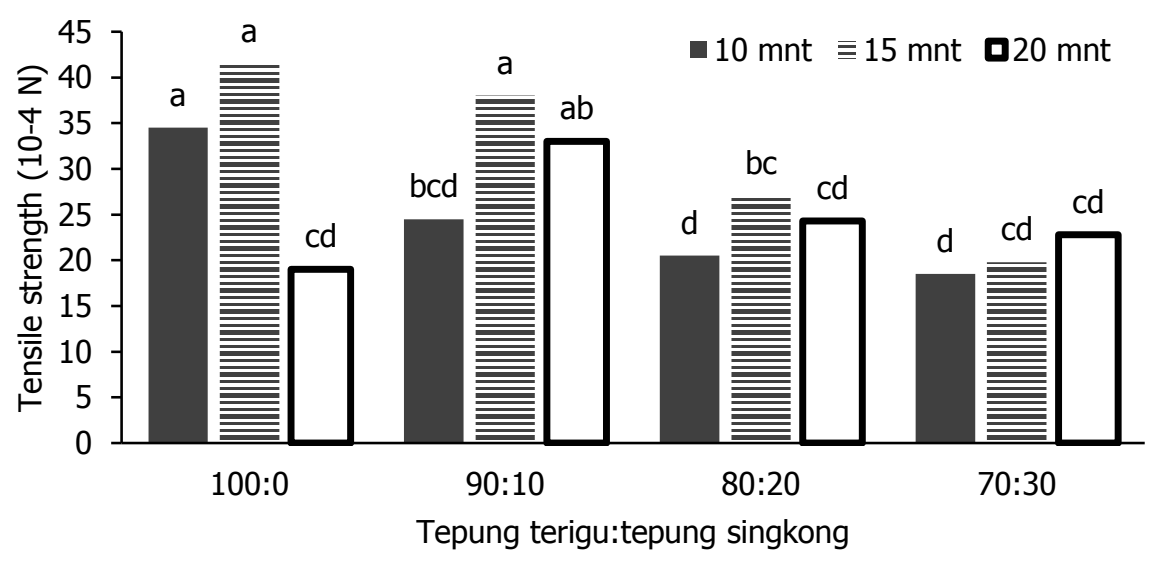

Gambar 2. Tensile strength adonan roti tawar dari tepung komposit terigu dan singkong dengan variasi lama pencampuran adonan.

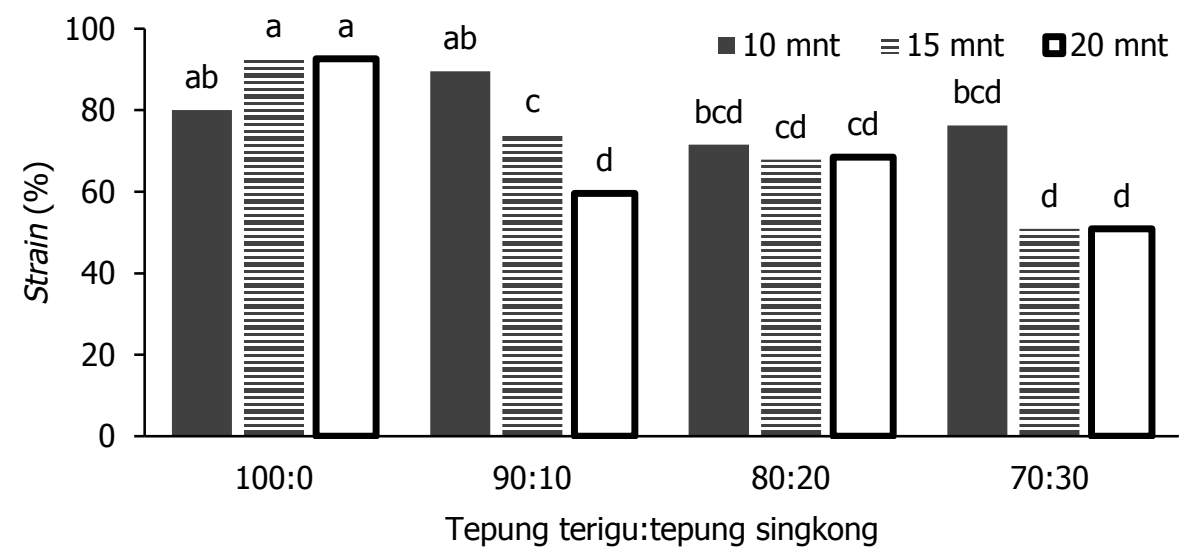

Gambar 3. Strain adonan roti tawar dari tepung komposit terigu dan singkong dengan variasi lama pencampuran adonan.

kandungan glutenin dalam protein gluten memiliki peran penting dalam menentukan kekuatan adonan. Selama proses pencampuran, gliadin dan glutenin dapat membentuk matriks protein melalui deformasi ikatan-ikatan silang non-kovalen dan ikatan disulfida. Menurut Mirsaeedghazi dkk. (2008), matriks protein yang terbentuk dapat memberikan tahanan terhadap gaya tarik

Lama pencampuran yang memberikan tensile strength tertinggi dari setiap rasio tepung komposit adalah 15 menit. Selama proses pencampuran dapat terbentuk jaringan protein yang kompleks (Bock dan Damodaran, 2013), karena terjadinya reaksi interchange tiol-disulfida dari gliadin dan glutenin (Shewry dkk., 2001). Peristiwa tersebut memungkinkan terjadinya ikatan non-kovalen yang dapat memperkuat atau memperlemah jaringan gluten (Bock dan Damodaran, 2003). Secara umum kelompok tiol dalam adonan dapat meningkatkan kelengketan adonan, sedangkan kelompok disulfida dapat meningkatkan kekuatan adonan. Mirsaeedghazi dkk. (2008) melaporkan bahwa pencampuran adonan yang dilakukan kurang dari waktu optimum dapat memberikan kekuatan adonan yang lebih rendah, karena ikatan silang disulfida yang terbentuk hanya sedikit. Menurut Bock dan Damodaran (2003), overmixing dapat mempercepat pecahnya interaksi antar struktur protein dikarenakan terjadinya perubahan daya ikat air dan menyebabkan peningkatan air bebas, sehingga tensile strength adonan menjadi lemah.

Dampak dari gaya tarik pada adonan adalah terjadinya deformasi yang ukurannya disebut strain (Dobraszczyk, 2003). Hasil penelitian pada Gambar 3 menunjukkan bahwa makin besar level penggunaan tepung singkong, semakin kecil nilai strain. Nilai strain adonan tertinggi ditunjukkan oleh adonan roti tawar 100:0 (15 menit) dan nilai strain adonan terendah diberikan oleh adonan roti tawar 70:30 (15 dan 20 
menit). Rauf dan Sarbini (2015) menyatakan bahwa makin besar level tepung singkong maka nilai strain adonan semakin kecil. Menurut Dobraszczyk, (2003), makin tinggi strain dari suatu adonan, semakin besar pengembangan adonan tersebut. Uthayakumaran dkk. (2000) menyebutkan bahwa kandungan protein sangat memengaruhi nilai strain adonan. Nilai strain adonan dapat semakin meningkat dengan meningkatnya kadar protein.

Lama pencampuran merupakan faktor yang turut memengaruhi strain adonan. Mathieu dkk. (2017) melaporkan bahwa pencampuran adonan yang singkat dapat menyebabkan pembentukan jaringan gluten yang tidak maksimal sehingga saat diregangkan adonan mudah putus. Sedangkan overmixing dapat menyebabkan terjadinya depolimerasi jaringan gluten. Jaringan gluten tersebut dapat mengalami kerusakan sehingga dapat menurunkan nilai strain dari adonan.

\section{Pengembangan Roti Tawar}

Hasil penelitian yang ditampilkan pada Gambar 4 menunjukkan adanya pengaruh nyata dari tepung komposit terigu dan singkong terhadap tingkat pengembangan roti tawar. Pengembangan tertinggi diberikan oleh perlakuan tepung komposit 90:10 (15 menit) yang berbeda tidak nyata dengan 100:0. Hasil ini sesuai dengan pengembangan adonan yang menunjukkan level tertinggi yaitu pada tepung komposit 90:10 (15 menit). Makin tinggi level tepung singkong, semakin rendah tingkat pengembangan roti tawar. Hal ini terkait dengan semakin berkurangnya kandungan gluten dari tepung komposit dengan semakin meningkatnya level tepung singkong. Borla dkk. (2004) melaporkan bahwa penambahan gluten pada tepung terigu dapat meningkatkan pengembangan roti tawar. Eriksson dkk. (2014) melaporkan bahwa makin tinggi level tepung singkong pada tepung komposit, semakin rendah tingkat pengembangan roti tawar.

Pengembangan roti tawar juga dipengaruhi oleh lama pencampuran adonan. Meskipun pada perlakuan 100:0 tidak menunjukkan adanya pengaruh lama pencampuran adonan, namun perlakuan tepung komposityang lain memberikan pengaruh yang signifikan. Perlakuan tepung komposit 90:10 pencampuran 15 menit menunjukkan tingkat pengembangan tertinggi, meskipun secara statistik tidak berbeda nyata dengan perlakuan 100:0. Sedangkan perlakuan 80:20 dan 70:30, pengembangan tertinggi berturut-turut yaitu dengan lama waktu 10 menit dan 15 menit. Tomoskozi \& Bekes (2016) menjelaskan bahwa lama pencampuran merupakan salah satu faktor penting yang menentukan tingkat pengembangan roti tawar. Osella dkk. (2007) melaporkan adanya pengaruh lama pencampuran terhadap tingkat pengembangan roti tawar.

\section{Tekstur Roti Tawar}

Hasil pengujian statistik menjelaskan adanya pengaruh nyata dari tepung komposit dan lama pencampuran terhadap tingkat kekerasan dan elastisitas roti tawar. Kekerasan roti tawar yang ditampilkan pada Gambar 5, menunjukkan bahwa makin besar level tepung singkong, semakin besar tingkat kekerasan roti tawar. Tingkat kekerasan tertinggi adalah roti tawar dengan tepung komposit terigu dan singkong 70:30, sedangkan yang terendah diberikan oleh roti tawar 100:0. Berdasarkan hasil ini tampak bahwa makin tinggi level tepung singkong yang berarti kadar gluten pada tepung komposit semakin rendah, semakin tinggi tingkat kekerasan roti tawar. Hasil ini sesuai dengan laporan Salmenkallio-Marttila (2004) bahwa penambahan gluten dapat menurunkan kekerasan roti tawar. Moore dkk. (2004) melaporkan bahwa roti tawar berbahan tepung terigu memberikan level kekerasan yang lebih rendah dari roti tawar berbahan tepung gluten-free.

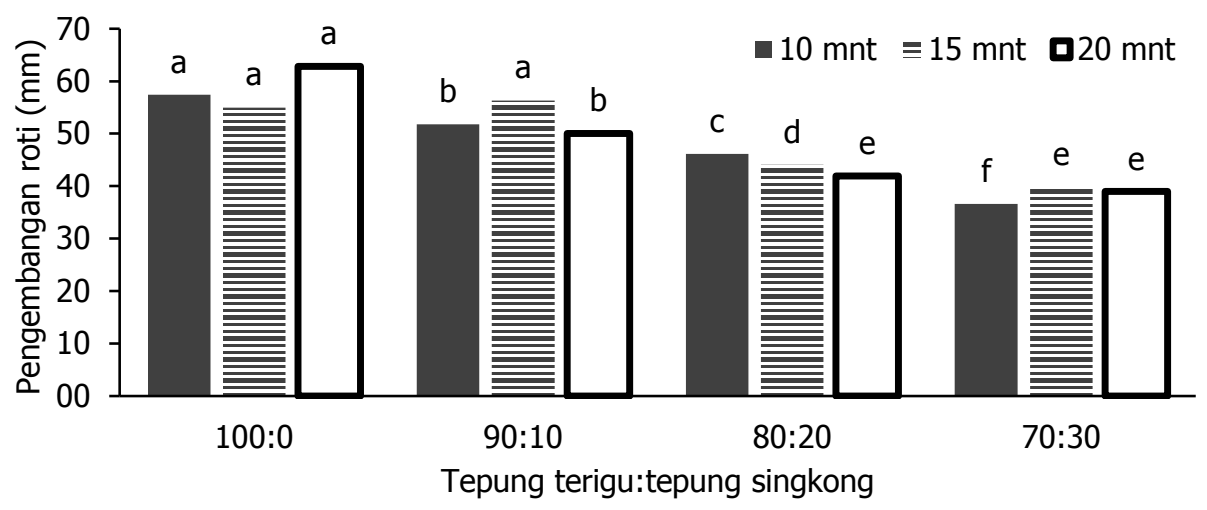

Gambar 4. Tingkat pengembangan roti tawar dari tepung komposit terigu dan singkong dengan variasi lama pencampuran adonan. 


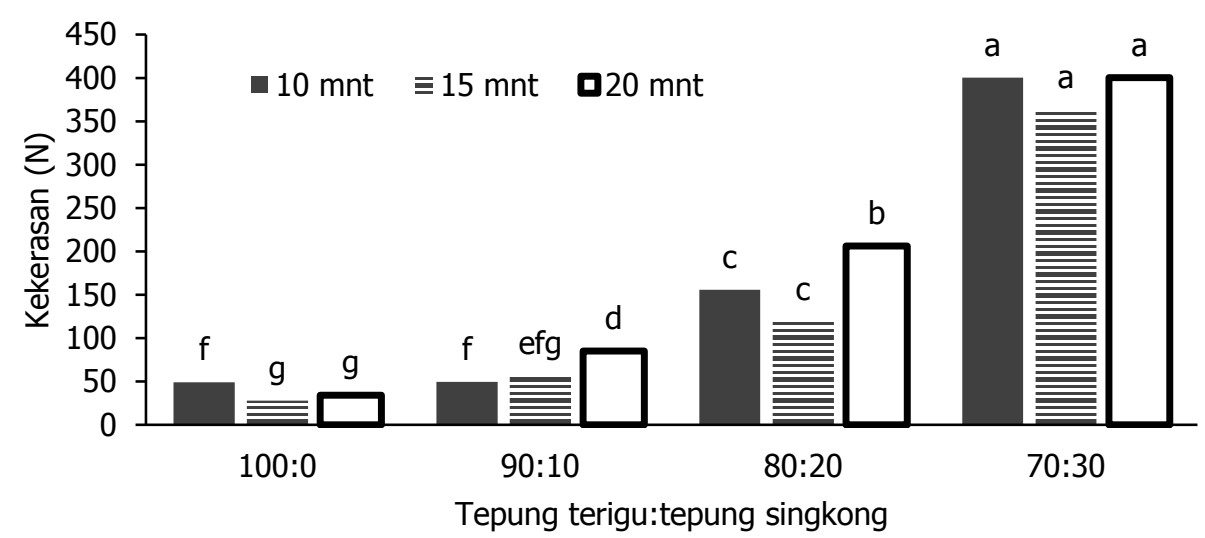

Gambar 5. Kekerasan roti tawar dari tepung komposit terigu dan singkong dengan variasi lama pencampuran adonan.

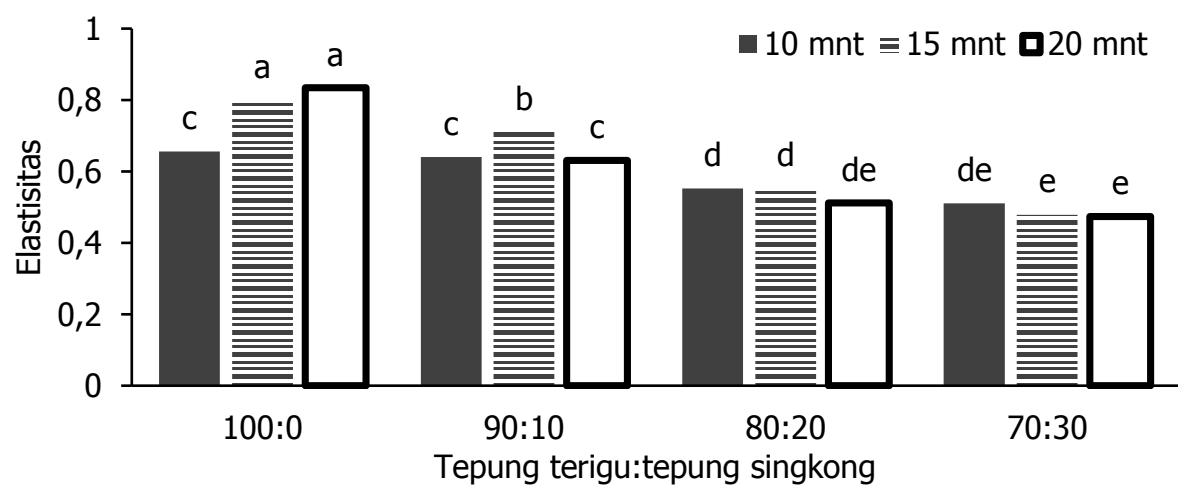

Gambar 6. Elastisitas roti tawar dari tepung komposit terigu dan singkong dengan variasi lama pencampuran adonan.

Kekerasan roti tawar, meskipun secara statistik dipengaruhi oleh lama pencampuran dan adanya interaksi antara tepung komposit dan lama pencampuran, namun pengaruh dari lama pencampuran tersebut tidak memberikan kecenderungan yang konsisten, seperti pada perlakuan 100:0, kekerasan tertinggi pada pencampuran 10 menit. Sebaliknya, perlakuan 90:10 dan 80:20 menunjukkan kekerasan tertinggi pada pencampuran 20 menit. Khusus untuk perlakuan 70:30, tidak ada pengaruh pencampuran terhadap kekerasan roti tawar. Pada produk roti tawar ini, faktor yang berpengaruh terhadap kekerasan semakin kompleks, termasuk kadar air (He dan Hoseney, 1990). Meskipun dalam penelitian ini tidak dilakukan pengujian kadar air, namun dugaan yang kuat dapat didasarkan pada karakteristik pasta dari komposit tepung terigu dan tepung singkong bahwa makin banyak tepung singkong yang digunakan, semakin mudah air dilepaskan dari pasta, yang menunjukkan bahwa kadar airnya semakin rendah (Rauf dan Sarbini, 2015). Lopez dkk. (2013) melaporkan bahwa ada hubungan antara peningkatan kekerasan dengan penurunan kadar air roti tawar.

Kekerasan roti tawar pada penelitian ini berbanding terbalik dengan elastisitas. Makin besar level tepung singkong dalam komposit, semakin rendah elastisitas roti tawar. Eriksson dkk. (2014) dan Rauf dkk. (2017) melaporkan bahwa makin banyak penggunaan tepung singkong, semakin rendah elastisitas roti tawar.

Gambaran pengaruh lama pencampuran terhadap elastisitas roti tawar tidak memberikan kecenderungan yang konsisten. Pada perlakuan 100:0 dan 90:10 tampak adanya pengaruh lama pencampuran. Elastisitas roti tawar 100:0 yang terendah terdapat pada perlakuan pencampuran 10 menit, sedangkan pada roti tawar 90:10, elastisitas terendah adalah pada pencampuran selama 20 menit yang berbeda tidak nyata dengan 10 menit. Sebaliknya, pada perlakuan 80:20 dan 70:30 tidak ada pengaruh lama pencampuran terhadap elastisitas roti tawar. Villarino dkk. (2014) dan Gomez dkk. (2012) melaporkan pengaruh lama pencampuran terhadap 
elastisitas roti tawar, namun nilai elastisitas tersebut tidak memberikan kecenderungan yang konsisten. Tomoskozi \& Bekes (2016) menyatakan bahwa setiap jenis tepung membutuhkan lama pencampuran yang spesifik untuk mendapatkan mutu roti yang optimum.

\section{Penerimaan Roti Tawar}

Hasil pengujian penerimaan sensorik roti tawar menunjukkan adanya pengaruh nyata dari rasio tepung komposit terigu dan singkong terhadap semua atribut penerimaan, yaitu warna, aroma, cecap, tekstur dan keseluruhan. Perlakuan tepung komposit 100:0 secara umum berbeda tidak nyata dengan perlakuan 90:10. Namun terdapat atribut kritis dari perlakuan 90:10 yang cukup signifikan lebih rendah dari perlakuan 100:0, yaitu atribut cecap. Hasil ini sesuai dengan penelitian Rauf dkk. (2017) bahwa terdapat perbedaan penerimaan cecap roti tawar yang signifikan antara perlakuan 100:0 dan 90:10 . Roti tawar dengan perlakuan 80:20 dan 70:30 secara umum untuk atribut warna, aroma, tekstur, cecap dan keseluruhan, menunjukkan penerimaan sensorik yang lebih rendah dibanding 100:0 dan 90:10. Agunbiade dkk. (2017) dan Eddy dkk. (2007) melaporkan bahwa makin banyak rasio komposit tepung singkong, semakin rendah penerimaan roti tawar.

Secara statistik, bahwa lama pencampuran berpengaruh tidak nyata terhadap semua atribut penerimaan roti tawar pada perlakuan tepung komposit yang sama, meskipun terdapat pengatuh nyata terhadap semua indikator fisik dari penelitian ini. Costell dkk. (2010) melaporkan bahwa respon dari panelis tidak selalu dapat didasarkan dari karakteristik sensory produk. Selain faktor fisiologis, faktor yang cukup kuat memengaruhi adalah persepsi, sikap, kepercayaan dan harapan dari panelis terkait produk tersebut.

\section{KESIMPULAN}

Rasio tepung komposit terigu dan singkong berpengaruh nyata terhadap tingkat pengembangan, tensile strength dan strain dari adonan. Makin tinggi proporsi tepung singkong, semakin rendah tingkat pengembangan, tensile strength dan strain dari adonan. Tingkat pengembangan, tensile strength, dan strain adonan tertinggi terdapat pada perlakuan tepung komposit 90:10 dengan pencampuran iptimum selama15 menit, yang berbeda tidak nyata dengan kontrol (100:0). Tingkat pengembangan roti tawar tertinggi adalah perlakuan 90:10 (15 menit) yang berbeda tidak nyata dengan 100:0. Makin tinggi level tepung singkong dari tepung komposit, semakin tinggi kekerasan roti tawar, sedangkan elastisitasnya semakin rendah. Penerimaan roti tawar dipengaruhi oleh rasio tepung komposit, sedangkan lama pencampuran memberikan pengaruh tidak nyata. Penerimaan mutu sensori pada roti tawar tertinggi terdapat pada perlakuan tepung komposit 90:10 yang berbeda tidak nyata dengan perlakuan 100:0.

\section{UCAPAN TERIMA KASIH}

Ucapan terima kasih disampaikan pada Universitas Muhammadiyah Surakarta atas dukungan dana pada program ini.

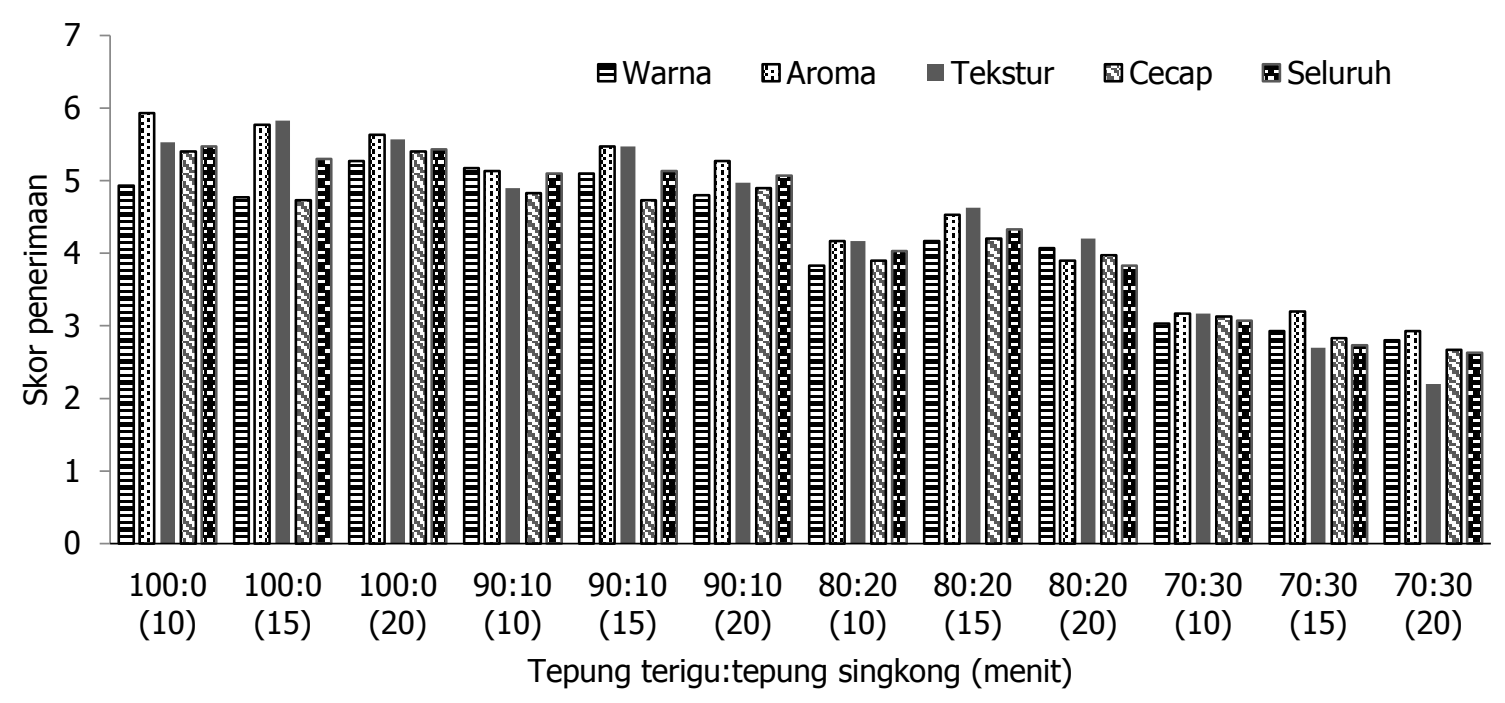

Gambar 7. Penerimaan sensorik roti tawar dari tepung komposit terigu dan singkong dengan variasi lama pencampuran adonan. 


\section{KONFLIK KEPENTINGAN}

Penulis menyatakan bahwa tidak ada konflik antar penulis atau dengan pihak lain.

\section{DAFTAR PUSTAKA}

Agunbiade, S. O., Ojezele, O. J., \& Eze, A. M. (2017). Maximizing the incorporation of cassava flour as an adjunct in bread baking in Nigeria. Chemistry International, 3(1): 92-96. doi.org/10.31221/osf.io/ qs572

APTINDO. (2018). Indonesia wheat flour consumption and growth. Asosiasi Produsen Tepung Terigu Indonesia. www.aptindo.or.id

Artan, M. Y., Karim, R., Chern, B. H., Ariffin, A. A., Man, Y. C., \& Nyuk, L.C. (2010). The influence of different formulation of palm oil/palm stearin-based shortenings on the quality of white bread. Middle-East Journal of Scientific Research, 5(6): 469-476.

Bock, J. E., \& Damodaran, S. (2013). Bran-induced changes in water structure and gluten conformation in model gluten dough studied by fourier transform infrared spectroscopy. Food Hydrocolloids, 31(2): 146-155. doi. org/10.1016/j.foodhyd.2012.10.014

Borla, O. P., Motta, E. L., Saiz, A. I., \& Fritz, R. (2004). Quality parameters and baking performance of commercial gluten flours. LWT- Food Science and Technology, 37(7): 723-729. doi.org/10.1016/j.Iwt.2004.02.013

Breshears, K. L., \& Crowe, K. M. (2013). Sensory and textural evaluation of gluten-free bread substituted with amaranth and montina ${ }^{\mathrm{TM}}$ flour. Journal of Food Research, 2(4): 1-10. doi.org/10.5539/jfr.v2n4p1

Casado, A., Alvarez, A., Gonzalez,L., Fernandez, D., Marcos, J. L., \& Tornadijo, M. E. (2017). Effect of fermentation on microbiological, physicochemical and physical characteristics of sourdough and impact of its use on bread quality. Czech Journal of Food Sciences, 35(6): 496-506. doi.org/10.17221/68/2017-cjfs

Codina, G. G., Mironeasa, S., Voica, D. V., \& Mironeasa, C. (2013). Multivariate analysis of wheat flour dough sugars, gas production, and dough development at different fermentation times. Czech Journal of Food Sciences, 31(3): 222-229. doi.org/10.17221/216/2012cjfs

Dhaka, V., \& Khatkar, B. S. (2015). Effects of gliadin/glutenin and HMW-GS/LMW-GS ratio on dough rheological properties and bread-making potential of wheat varieties. Journal of Food Quality, 38: 71-82. doi.org/10.1111/jfq. 12122

Dobraszczyk, B. J. (2003). The physics of baking: rheological and polymer molecular structure-function relationships in breadmaking. Polish Journal of Food and Nutrition
Sciences, 12(53): 24-31. doi.org/10.1016/j. jnnfm.2004.07.014

Costell, E., Tárrega, A., \& Bayarri, S. (2010) Food acceptance: the role of consumer perception and attitudes. Chemosensory Perception, 3(1): 42-50. doi.org/10.1007/ s12078-009-9057-1

Eddy, N. O., Udofia, P. G., \& Eyo, D. (2007). Sensory evaluation of wheat/cassava composite bread and effect of label information on acceptance and preference. African Journal of Biotechnology, 6(20): 2415-2418. doi. org/10.5897/ajb2007.000-2379

Eriksson, E., Koch, K., Tortoe. C., Akonor. P. T., \& OduroYeboah, C. (2014). Evaluation of the physical and sensorycharacteristics of bread produced from three varieties of cassava and wheat composite flours. Food and Public Health, 4(5): 214-222. doi:10.5923/j. fph.20140405.02

Gomez, A., Ferrero, C., Calvelo, A., Anon, M. C., \& Puppo, M. C. (2011). Effect of mixing time on structural and rheological properties of wheat flour dough for breadmaking. International Journal of Food Properties, 14(03): 583-598. doi.org/10.1080/10942910903295939

Gomez, M., Talegon, M., \& Hera E. D. L. (2012). Influence of mixing on quality of gluten-free bread. Journal of Food Quality, 36: 139-145. doi.org/10.1111/jfq.12014

He, H., \& Hoseney, R. C. (1990). Changes in bread firmness and moisture during long-term storage. Cereal Chemistry, 67(6): 603-605.

Kementan. (2017). Statistik konsumsi pangan tahun 2017. Jakarta: Pusat Data dan Sistem Informasi Pertanian, Kementerian Pertanian.

Lawless, H. T., \& Heymann, H. (2010). Sensory Evaluation of Food: Principles and Practices (2nd ed.). New York: Springer.

Lemley, K. V., Faul, C., Schramm, K., Meyers, K., Kaskel, F., Dell, K. M., Gipson, D. S, Gibson, K., \& Tracchtman, H. (2016). The Effect of a gluten-free diet in children with difficult-to-manage nephrotic syndrome. Pediatrics, 134(1): 1-7. doi.org/10.1542/peds.2015-4528

Lopez, E. P., Perez, G. T., Erramouspe, J. P. L., Cuevas, C. M. (2013). Effect of Brea Gum on the characteristics of wheat bread at different storage times. Food Science and Technology, Campinas, 33(4): 745-752. doi. org/10.1590/s0101-20612013000400021

Masamba, K, \& Jinazali, H. (2014). Effect of cassava processing methods and substitution level on proximate composition, sensory characteristics and overal acceptability of bread made from wheat-cassava flour blends. African Jurnal of Food, Agriculture, Nutrition and Development, 14(6): 2190-2203.

Mathieu, M., Ruth, C., Filip, O., Christophe., Paula, M. (2017). The impact of water content and mixing time on the 
linear and non-linear rheology of wheat flour dough. Food Biophysics, 12(2): 151-163. doi.org/10.1007/ s11483-017-9472-9

Milcah, W., Joseph, W. M., Abdul, K. F., \& Peter, L. O. (2016). Effect of different cassava varieties (manihotesculenta) and substitution levels in baking of wheat-cassava composite bread on physical properties and sensory characteristics. African Journal of Food Science and Technology, 7(6): 131-139. doi.org/10.14303/ ajfst.2016.071

Mirsaeedghazi, H., Emam-Djomeh, Z., \& Mousavi, S. M. A. (2008). Rheometric measurement of dough rheological characteristics and factors affecting it. International Journal of Agriculture and Biology, 10: 112-119.

Moore, M. M., Schober, T. J., Dockery, P., \& Arendt, E. K. (2004). Textural comparisons of gluten-free and wheatbased doughs, batters, and breads. Cereal Chemistry, 81(5): 567-575. doi.org/10.1094/cchem.2004.81.5.567

Niland, B., \& Cash, D. (2018). Health benefits and adverse effects of a gluten-free diet in non-celiac disease patients. Gastroenterology \& Hepatology, 14(2): 82-91.

Nwosu, Justina, N. O., Omeire, G. C., \& Eke, C. C. (2014). Quality parameters of bread produced from substitution of wheat flour with cassava flour using soybean as an improver. American Journal of Research Communication, 2(3): 99-118.

Osella, C. A., Sanchez, H. D., \& Torre, M. A. (2007). Effect of Dough water content and mixing conditions on energy imparted to dough and bread quality. Cereal Foods World, 52(2): 70-73. doi.org/10.1094/cfw-52-2-0070

Rauf, R. (2015). Kimia Pangan. Yogyakarta, Indonesia: Penerbit Andi.

Rauf, R., \& Sarbini, D. (2015). Daya serap air sebagai acuan untuk menentukan volume air dalam pembuatan adonan roti tawar campuran tepung terigu dan tepung singkong. Jurnal Agritech, 35(3): 324-330. doi.org/10.22146/ agritech.9344

Rauf, R., Sarbini, D., \& Nurdiana. 2017. Optimization of Fermentation Time on Physical Characteristics and Sensory Acceptance of Bread from Composite Wheat and Cassava Flours with Proporsional Water Volume. In International Conference on Science, Technology, and Humanity. Surakarta, Indonesia.
Różył, R., Dziki, D., Gawlik-Dziki, U., Cacak-Pietrzak, G., Miś, A., \& Rudy, S. (2015). Physical properties of gluten-free bread caused by water addition. International Agrophysics, 29: 353-364. doi.org/10.1515/intag-2015-0042

Salmenkallio-Marttila, M., Roininen, K., Autio, K., \& Lähteenmäki, L. (2004). Effects of gluten and transglutaminase on microstructure, sensory characteristics and instrumental texture of oat bread. Agricultural and Food Science, 13: 138-150. doi.org/10.2137/1239099041838003

Scanlon, MG., \& Zghal, MC. 2001. Bread Properties and Crumb Structure. Food Research International, 34(10): 841864. doi.org/10.1016/s0963-9969(01)00109-0

Shewry, P.R., Popineau, Y., Lafiandra, D., \& Belton, P.(2001). Wheat glutenin subunits and dough elasticity: findings of the eurowheat project. Trends in Food Science and Technology, 11: 433-441. doi.org/10.1016/s09242244(01)00035-8

Singh, N., Gujral, H. S., \& Singh, J. (2002). Effect of baking ingredients and mixing duration on dough development, gas release and bread making properties. Journal of Food Quality, 25: 305-315. doi.org/10.1111/j.1745-4557.2002. tb01027.x

Sroan, B. S., Bean, S. R., \& MacRitchie, F. (2009). Mechanism of gas cell stabilization in bread making. I. The primary gluten-starch matrix. Journal of Cereal Science, 49: 3240. doi.org/10.1016/j.jcs.2008.07.003

Tomoskozi, S., \& Bekes, F. (2016). Bread: dough mixing and testing operations. Encyclopedia of Food and Health: 490-499. doi.org/10.1016/b978-0-12-384947-2.000866

Uthayakumaran, S., Newberry, M., Keentok, M., Stoddard, F. L., \& Bekes, F. (2000). Basic rheology of bread dough with modified protein and glutenin-to-gliadin ratios. Cereal Chemistry, 77(6): 744-749. doi.org/10.1094/ cchem.2000.77.6.744

Villarino, C. B., Jayasena, V., Coorey, R., Chakrabarti-Bell, S., \& Johnson, S. (2014). The effects of bread-making process factors on Australian sweet lupin-wheat bread quality characteristics. International Journal of Food Science \& Technology, 49: 2373-2381. doi.org/10.1111/ijfs.12595

Weiser, H. 2007. Chemistry of gluten protein. Food Microbiology, 24(2): 155-119. doi.org/10.1016/j.fm.2006.07.004 